\title{
Timothy Grass Pollen IgE Measurement
}

National Cancer Institute

\section{Source}

National Cancer Institute. Timothy Grass Pollen IgE Measurement. NCI Thesaurus. Code C130088.

A measurement of the Timothy grass (Phleum pretense) pollen IgE in a biological specimen. 